\title{
Concordant paleomagnetic directions from the Tehuantepec Isthmus: Constraints on the Neogene evolution of the North American-Caribbean plate boundary
}

\author{
Roberto S. Molina-Garza ${ }^{a}$, Jaime Urrutia-Fucugauchi ${ }^{b}$, Rob Van der Voo ${ }^{\mathrm{c}}$ \\ a Department of Earth and Planetary Sciences, University of New Mexico, Albuquerque, NM 87131-1116, USA \\ ${ }^{\mathrm{b}}$ Laboratorio de Paleomagnetismo, Instituto de Geofisica, UNAM, Coyoacan 04510 D.F., Mexico \\ ${ }^{c}$ Department of Geological Sciences, University of Michigan, Ann Arbor, MI 48109-1063, USA
}

Received 12 August, 1993; accepted 17 March 1994

\begin{abstract}
We report paleomagnetic data for Miocene igneous rocks of the southeastern Tehuantepec Isthmus region, Mexico. Thermal and alternating field demagnetization reveal predominantly normal polarity magnetization, interpreted as primary TRM. The overall mean direction ( $\mathrm{Dec}=355.6^{\circ}, \mathrm{Inc}=36.5^{\circ}, k=36.4, a_{95}=9.3^{\circ}, N=8$ sites) is statistically indistinguishable from the expected direction, calculated using the North American reference pole. This result indicates that significant rotation or displacement of the Tehuantepec region relative to the craton has not occurred since $13 \mathrm{Ma}$.
\end{abstract}

\section{Introduction}

Tertiary tectonics of southern Mexico and northern Central America has been related to the interactions of the Cocos (Farallon), Caribbean, and North American plates (Molnar and Sykes, 1969; Jordan, 1975; Burkart, 1983). The Cocos plate is subducted beneath the Caribbean and North American plates along the Middle America Trench (MAT; Fig. 1), whereas the boundary between the Caribbean and North American plates is a complex set of left-lateral transform faults. The North America-Caribbean plate boundary includes the Motagua, Jocotan, and Polochic systems in Honduras, Guatemala, and adjacent Mexico (Burkart, 1978; Schwartz et al.,
1979). Offshore, in the Caribbean sea, the boundary extends along the Cayman Trough (Holcombe and Sharman, 1983).

The region has presented many long standing problems in explaining its tectonic evolution and even its present tectonic relationships. Several lines of evidence on land point to a modest $(\sim 130 \mathrm{~km})$ left-lateral offset along the CuilcoChixoy-Polochic system (CCP) since about $15 \mathrm{Ma}$ (Burkart, 1978, 1983; Burkart et al., 1987). Movement along the Jocotan and Motagua systems is less well determined. They do not have a geomorphic expression in the Miocene rocks that cover their western extension and do not produce sizeable offset in the Quaternary volcanic arc. In contrast, the eastern extension of the plate 

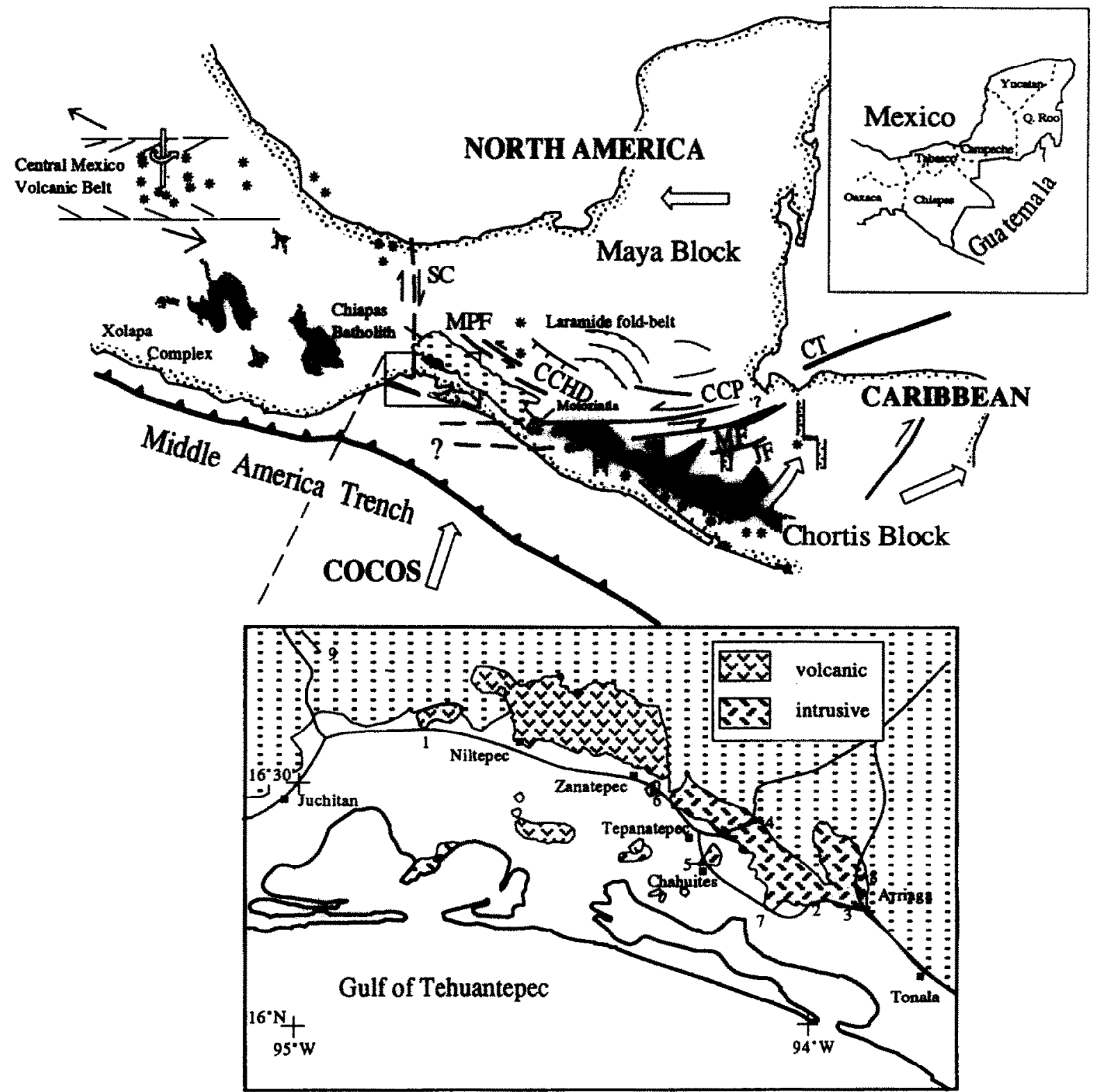

Fig. 1. Schematic representation of the plate tectonic arrangement of the Cocos, North America, and Caribbean plates. Open arrows represent relative motion directions. Those for northern Central America and central Mexico are indicative of block rotation (Urrutia-Fucugauchi and Böhnel, 1988; Burkart and Self, 1985). Arcuate strike-slip faults and north-south-trending grabens characterize Central Guatemala and Honduras. Central Chiapas is also characterized by a major WNW-ESE depression (Central Chiapas Depression, CCHD). Major faults with lateral displacement are shown with solid lines (dashed where uncertain). Normal faults have tick-marks on the down-thrown block. Thrust faults are also indicated on the eastern Chiapas Laramide fold belt. Miocene volcanic provinces of southern Mexico and Central America are indicated with a dark pattern and asterisks indicate main Quaternary volcanic centers. Enlarged area: map of the southern Isthmus of Tehuantepec region showing paleomagnetic sites (1 through 9) and areal exposure of Cenozoic volcanic and intrusive rocks. The dotted pattern includes undifferentiated pre-Cenozoic rocks of the Chiapas Batholith. Symbols on the map are: $S C=$ Salina Cruz fault; $C C P=C u i l c o-C h i x o y-P o l o c h i c$ fault system; $M F=$ Motagua fault system; $J F=$ Jocotan fault system; $M P F=$ Malpaso fault system; $C T=$ Cayman Trough. 
boundary in the Cayman Trough indicates as much as $450 \mathrm{~km}$ of left-lateral displacement in the Neogene (Holcombe and Sharman, 1984) and a collective Cenozoic offset of $\sim 1,000 \mathrm{~km}$ (Rosencrantz et al., 1988). Burkart and Self (1985) postulated that internal deformation (extension and terrane rotation) along the transform boundary in Guatemala and Honduras can account for a substantial part of the Neogene displacement observed offshore. Extensional structures (e.g., pull-apart basins) and segmentation of the volcanic arc appear to have been active at least during the Neogene (Schwartz et al., 1979; Burkart, 1983; Carr, 1984). Early Cenozoic movements along the Jocotan, Motagua, and Polochic systems are, however, controversial.

The characteristics of the subduction zone and associated magmatic arc show a marked contrast across the transform boundary. The region of the Isthmus of Tehuantepec in southern Mexico appears as a zone of transition from shallow subduction dip angles beneath southwestern Mexico to steeper angles beneath Chiapas and Central America. The volcanic activity shows a discontinuity from the well-defined, close-to-the-margin Central American arc parallel to the MAT, to the oblique and somewhat irregularly distributed pattern of southern Mexico (Fig. 1).

The location and nature of the place where the three plates come together is also a matter of debate. The present plate geometry and plate velocities indicate that a theoretical triple junction (trench-trench transform) between North America, Cocos and Caribbean should be unstable. Thus past plate boundary configurations are difficult to incorporate in a tectonic model for the region. The evolution of the triple junction is likely responsible for the complex deformation pattern in this area. Although most models have assumed that the Polochic or Motagua faults, or both, intersect the Middle America Trench (Burkart, 1983), a lineation of seismicity oriented northwest-southeast in central Chiapas (the Malpaso fault system) has been interpreted by Guzman-Speziale et al. (1989) as a significant plate boundary, In the model of Guzman-Speziale et al. (1989), the rcgion of western Chiapas (and offshore) is a small wedge of the Caribbean plate trapped between the North America and Caribbean plates. In the model proposed by Burkart and Self (1985), the tectonic and volcanic pattern in northern Central America (the Chortis Block; Dengo, 1969) and adjacent Chiapas (south of the CCP system) is the result of eastward rotation and differential movement of crustal blocks over the subduction-controlled zone of magma production (Fig. 1). The model of Guzman-Speziale et al. (1989) predicts that the extensional tectonic regime and block rotations of central Guatemala should extend into westernmost Chiapas.

In contrast to seismic activity, which yields a snapshot view of stress accumulation and relief along plate boundaries, paleomagnetic data may provide evidence of a longer lasting stress regime. Paleomagnetic directions can be interpreted in terms of past or present tectonic regimes. Discordant paleomagnetic directions of Cenozoic volcanic, plutonic, and sedimentary units of the Central Mexico Volcanic Belt have been interpreted in terms of counterclockwise rotations of small crustal blocks in response to large scale left-lateral shear (shown schematically in Fig. 1) within a transtensional environment (Urrutia-Fucugauchi and Böhnel, 1988). Regional stress and faulting in the volcanic belt appear to be related to complex plate interactions and reorganization in the $\mathrm{Pa}$ cific region (Mammerickx and Klitgord, 1982). Interestingly, paleomagnetic data for Cretaceous through Tertiary rocks in southern Mexico terranes (south of the Central Mexico Volcanic Belt) including Early Cretaccous rocks overlying the Chiapas Batholith, suggest stability with respect to the craton. In fact, paleomagnetic data preclude major tectonic movements other than latitude-parallel motion (Urrutia-Fucugauchi et al., 1987; Böhnel et al., 1988, 1989; UrrutiaFucugauchi, 1988; Guerrero et al., 1990). Paleomagnetic data for the Chortis Block are scarce, but Late Jurassic through Eocene data clearly show large-magnitude rotations with respect to southern Mexico accompanied by relative southwards motion (Gose, 1985). The paleomagnetic data from the Chortis Block are compatible with models that suggest it has been adjacent to southwest Mexico since Early Cretaceous times (Pindell and Barrett, 1990). 
In this study we report paleomagnetic data for Late Cenozoic volcanic and plutonic units exposed along the Pacific coastal plain in the southeastern portion of the Isthmus of Tehuantepec. This locality is presently northeast of the projected intersection of the MAT and the CCP fault system, the most northern of the left-lateral fault systems at the North America-Caribbean boundary. Paleomagnetic samples were obtained from Late Cenozoic rocks to examine whether tectonic rotations such as proposed for northern Central America or like those observed in Central Mexico could be detected in this region. If observed, and if the primary nature or otherwise origin of the results can be established, the amount and sense of rotation should be related to Miocene or younger evolution of the triple-junction or the plate boundaries. In contrast, concordant paleomagnetic direction can be interpreted to indicate tectonic stability.

\section{Geology and sampling}

The southeastern portion of the Pacific coastal plain in the Tehuantepec Isthmus region is characterized by Miocene volcanic, subvolcanic, and plutonic rocks (Damon and Montesinos, 1978; Burkart, 1983) which in part intrude the late Paleozoic Chiapas Batholith and the Mesozoic sedimentary cover (Fig. 1). These units represent the ancient location of a magmatic arc that extended to the south into the Motozintla region in the vicinity of the CCP system in Miocene times. The present locus of the magmatic activity east of the Chiapas Batholith has resulted from migration of the magmatic front as a consequence of Late Miocene plate reorganization (UrrutiaFucugauchi, 1987).

The units sampled in the present study comprise the granodioritic intrusions exposed along the Pan American highway between San Pedro
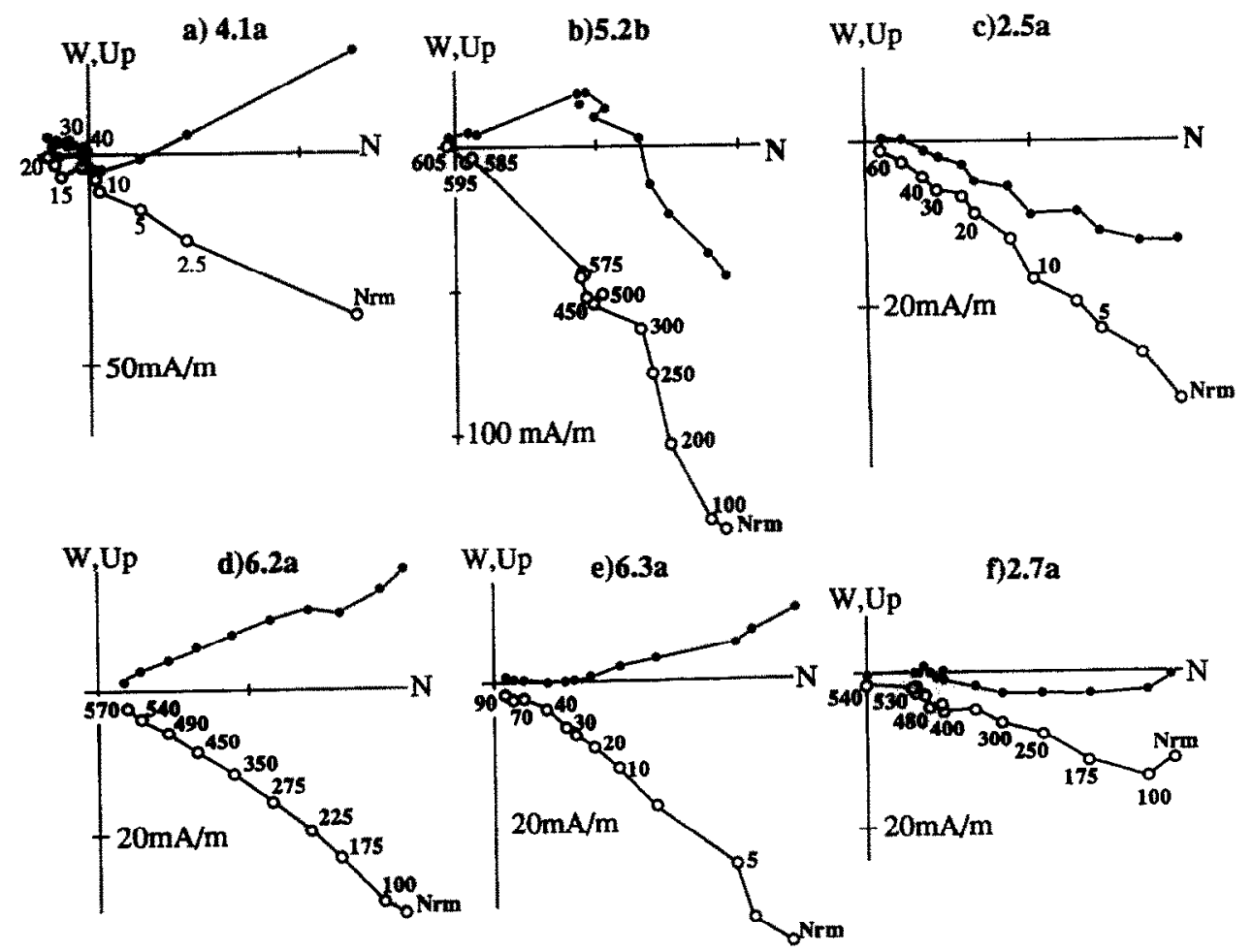

f) $2.7 a$

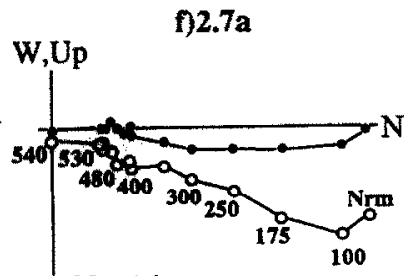

$20 \mathrm{~mA} / \mathrm{m}$

Fig. 2. Orthogonal demagnetization diagrams (Zijderveld, 1967). Full symbols (open) indicate projection onto the horizontal (vertical) plane. (a)-(c) and (f) are granodiorite samples, whereas (d) and (e) are typical examples of volcanic rocks. Temperatures are in ${ }^{\circ} \mathrm{C}$ and induction fields are in $\mathrm{mT}$. (a) is an example of a sample carrying a reverse polarity magnetization. 
Tepanatepec and Arriaga (sites 2-5, 7, 8; Fig. 1) and age-equivalent dacitic flows in the Niltepec and Zanatepec area (sites 1,6, and 9). K-Ar age determinations for the granodiorite intrusions range between 12.4 and $13 \mathrm{Ma}$ (Damon and Montesinos, 1978). A total of 51 samples (9 sites) were collected in the field using a portable drill and oriented using a magnetic compass. The intensity of the magnetization of the material collected is moderate and does not influence orientation of drilled cores. In the laboratory one or two specimens $2.1 \mathrm{~cm}$ in length were obtained from each sample.

\section{Paleomagnetic results}

Natural remanent magnetization (NRM) measurements were made with either a ScT two axis cryogenic magnetometer or a Schonstedt spinner magnetometer in a magnetically shielded room at the paleomagnetic laboratory of the University of Michigan. NRM intensities range between 2 and $100 \mathrm{~mA} / \mathrm{m}$; NRM directions are well clustered and plot on the lower hemisphere of the stereonet with northerly declinations and intermediate inclinations. Stability of the NRM was studied by conventional stepwise alternating field (AF) and thermal demagnetization up to peak inductions of $100 \mathrm{mT}$ or temperatures of $620^{\circ} \mathrm{C}$ (respectively). Typical orthogonal demagnetization diagrams (Zijderveld, 1967) are shown in Fig. 2. The majority of the samples are characterized by a relatively simple behavior upon demagnetization. A low coercivity and intermediate laboratory unblocking temperature is removed at inductions of $20 \mathrm{mT}$ or about $400^{\circ} \mathrm{C}$. The remaining magnetization unblocks at temperatures that range between 500 and $590^{\circ} \mathrm{C}$. The high temperature component is in some cases stable, both in direction and intensity, up to AF peak inductions of $90 \mathrm{mT}$ (Fig. 2e). More commonly this component is removed by AF inductions of 40 to $90 \mathrm{mT}$. This magnetization is considered the characteristic magnetization (ChRM). In at least one site the ChRM is of reverse polarity (Fig. 2a). This is revealed only in the $A F$ demagnetization experiments of two samples thus its direction is not well determined.

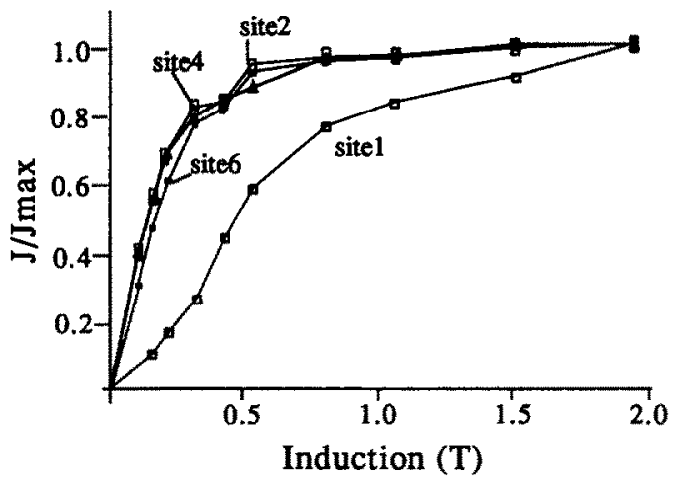

Fig. 3. Normalized isothermal remanent magnetization acquisition curves for selected specimens. The great majority of the samples saturate with inductions typical of titanomagnetite. The exception to this behavior are samples from volcanic rocks sampled at site 1 which show characteristic curves of titanohematite.

Experiments of isothermal remanent magnetization (IRM) acquisition are shown in Fig. 3. Samples nearly saturate at inductions of less than $0.4 \mathrm{~T}$. Both the unblocking temperatures observed and the IRM acquisition experiments indicate that the magnetization is carried by minerals of the titanomagnetite (or titanomaghemite) series. Samples from site 1 do not reach saturation at $2.0 \mathrm{~T}$ inductions. However, the magnetization unblocks at temperatures of less than $600^{\circ} \mathrm{C}$. It is thus possible that the magnetization in samples from site 1 is carried by titanohematites.

Reflected light microscopy in selected granodiorite samples indicated relatively abundant grains, tens of microns in size, of magnetite with abundant lamellae of exsolved ilmenite. Minor hematite was present at oxidized rims and fractures of magnetite grains. Hematite was also abundant in samples of site 1 and appears magmatic in origin.

\section{Discussion}

Magnetization directions were calculated using the method of principal component analysis (PCA) of Kirschvink (1980). Only specimens with maximum angular deviation (MAD) values of less than $10^{\circ}$ were included in the site mean calculation, although MAD values rarely exceed $5^{\circ}$. 
Table 1

Paleomagnetic data and Fischer's statistical parameters for Late Cenozoic igneous rocks in the southeastern Tehuantepec region, Mexico

\begin{tabular}{lrrrrr}
\hline Site & $n_{\mathrm{d}} n$ & Decl. $\left(^{\circ}\right)$ & \multicolumn{1}{c}{ Incl. $\left(^{\circ}\right)$} & \multicolumn{1}{c}{$k$} & \multicolumn{1}{c}{$\alpha_{45}$} \\
\hline $1^{*}$ & 55 & 358.9 & 37.0 & 229.0 & 5.1 \\
2 & 86 & 1.1 & 30.1 & 17.6 & 18.8 \\
4 & 42 & 195.2 & -31.1 & & \\
5 & 33 & 338.4 & 50.2 & 137.0 & 10.6 \\
$6^{*}$ & 55 & 345.8 & 37.3 & 37.5 & 11.1 \\
7 & 75 & 347.7 & 26.6 & 24.1 & 19.1 \\
8 & 55 & 13.7 & 39.7 & 13.7 & 21.0 \\
$9 *$ & 64 & 340.8 & 34.6 & 64.6 & 11.5 \\
Mean & 8 & 355.6 & 36.5 & 36.4 & 9.3 \\
\hline
\end{tabular}

$\overline{n_{\mathrm{d}} / n=\text { number of samples demagnetized } \backslash \text { included in the }}$ site mean.

* Sites collected in volcanic rocks.

Samples from site 3 do not show internal coherence and will not be discussed any further. The first component removed is interpreted as a secondary magnetization of viscous origin (VRM). The high coercivity (and temperature) magnetization is interpreted as a primary magnetization of thermal origin (TRM). This interpretation is supported by the observation of both normal and reverse polarities. Furthermore, samples of the late Paleozoic Chiapas Batholith collected near the contact with the Miocene coastal batholith (Molina-Garza et al., 1992) have north-directed and positive magnetization overprints. These overprinting magnetizations are often stable up to temperatures of $650^{\circ} \mathrm{C}$ and can be interpreted as remagnetizations of thermal (or hydrothermal) origin associated with the Miocene intrusions sampled in this study.

Paleomagnetic directions and statistical parameters are listed in Table 1. Sample direction distributions and site mean directions with confidence intervals are plotted in Fig. 4. The excellent agreement between the results of volcanic and intrusive units indicate that significant tilt of the intrusives has not occurred since emplacement and cooling. In order to calculate a mean paleomagnetic direction representative of the Middle Miocene paleofield, site means were combined using Fisher statistics assigning unit weight to each site. The overall mean (Dec $=355.6^{\circ}$, Inc $=36.5^{\circ}, k=36.4, a_{45}=9.3^{\circ}, n=8$ sites) is statistically indistinguishable from the expected paleomagnetic direction $\left(359.5^{\circ},+27^{\circ}, \pm 3^{\circ}\right)$ calculated using the Late Cenozoic cratonic reference pole of Irving and Irving (1982). This result indicates that significant rotation or displacement of the Tehuantepec region relative to the North

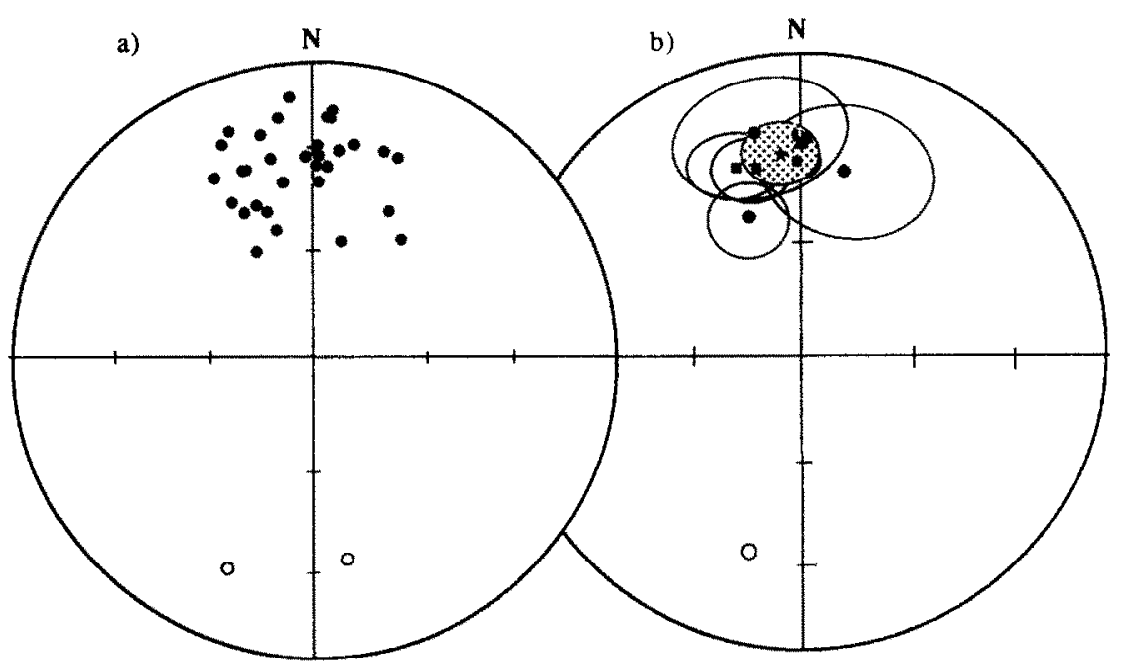

Fig. 4. (a) Equal-area stereographic projection of sample characteristic magnetizations calculated by principal component analysis after demagnetization. (b) Site means and $95 \%$ confidence circles. Directions are plotted in in-situ coordinates. A triangle indicates the expected present dipole-field direction and a diamond indicates the expected late Cenozoic direction according the Irving and Irving (1982). Squares (circles) are sites collected in volcanic (intrusive) rocks. The overall mean is indicated with a star. 
American craton has not occurred since the last $13 \mathrm{Ma}$.

This result does not directly quantify the amount of displacement associated with motion along the Caribbean-North America transform plate boundary (Burkart, 1978) nor it can be used to quantify displacement along the north-south trending Salina Cruz fault along the Isthmus of Tehuantepec (Viniegra, 1971) or the east-southeast-trending Malpaso fault on the eastern margin of the Chiapas Batholith (Meneses-Rocha, 1985). Within the statistical uncertainties, however, paleomagnetic data do not indicate large latitudinal translation or rotation as proposed in plate tectonic models of the area (e.g., Ross and Scotese, 1988; Guzman-Speziale et al., 1989).

The tectonics of Chiapas and adjacent areas is complicated, late Tertiary faulting is superimposed on Laramide (early Tertiary) compressional deformation. Laramide folding and thrusting are more intense in eastern Chiapas, whereas deformation in the Tehuantepec Isthmus is relatively mild. Unlike Central Guatemala, east-west extension is not characteristic of southern Mexico. Instead, east-west-trending normal (gravity) faults are present in the Central Chiapas depression west of the Chiapas Batholith (Fig. 1) and further north in the Gulf region. Strike-slip faulting (left-lateral) in the Malpaso fault initiated in Cretaceous times and appears to have lasted through Oligocene times (Viniegra, 1971). Maximum displacement measured along the Malpaso fault is of about $10 \mathrm{~km}$ (Viniegra, 1971). Motion along the Salina Cruz fault appears to date from the late Tertiary but is poorly documented, surface indications of major faulting are lacking. In fact, the existence of the Salina Cruz fault has been inferred from the change in tectonic style of the Laramide fold-belt across the isthmus.

The Late Cretaceous and Tertiary evolution of the southern Mexico continental margin have been dictated by terrane accretion (Campa and Coney, 1983; Böhnel et al., 1988, 1989) and continental truncation which involved southeast motion of the Chortis Block with respect to southern Mexico (Anderson and Schmidt, 1983; Pindell and Barrett, 1990). East-west-trending sub-vertical mylonite zones with left-lateral slip cut Ter- tiary intrusive bodies in southwest Mexico in the Xolapa Complex west of our sampling sites (Tolson et al., 1993). Radiometric age determination for the intrusives provide maximum ages for the mylonites and become progressively younger to the east, towards the present location of the CCP system (Tolson et al., 1993). Mylonites cut the Miocene granodiorites and Permian granites north of the town of Tonala (Fig. 1). Like the Miocene rocks studied here, intrusive rocks in the Xolapa terrane give paleomagnetic results in general agreement with the North America reference (Böhnel et al., 1988). It thus appears that western Chiapas and the Tehuantepec region share a Cenozoic evolution which resembles that of the continental margin of southwest Mexico (Böhnel et al., 1988, 1989; Tolson et al., 1993). Rotations related with extensional features and/or intraplate deformation may thus be restricted to the plate boundary zone between the North America and Caribbean plates and nuclear Central America (Burkart and Self, 1985). Concordant paleomagnetic data from this pilot study suggest that the late Paleozoic Chiapas Batholith did not follow the Tertiary evolution of the Chortis Block. Independent stratigraphic and paleogeographic evidence relate the Chiapas Batholith to the Maya Block at least since Late Jurassic times (Anderson and Schmidt, 1983).

\section{References}

Anderson, T.H. and Schmidt, V.A., 1983. The evolution of the Gulf of Mexico-Caribbean Sea region during Mesozoic time. Geol. Soc. Am. Bull., 94: 941-966.

Böhnel, H., Negendank, J.F.W. and Urrutia-Fucugauchi, J., 1988. Paleomagnetism and ore petrology of three Cretaceous-Tertiary batholiths of southern Mexico. N. Ih. Greol. Paläont. Monatsh., 2: 97-127.

Böhnel, H., Alva-Valdivia, L., Gonzalez-Huesca, S., UrrutiaFucugauchi, J., Moran-Zenteno, D.J., and Schaaf, P., 1989. Paleomagnetic data and the accretion of the Guerrero terrane, southern Mexico continental margin. J.W. Hillhouse (Editor), Deep Structure and Past Kinematics of Accreted Terranes, IUGG vol. 5. Am. Geophys. Union, Geophys. Monogr, 50: 73-92.

Burkart, B., 1978. Offset across the Polochic fault of Guatemala and Chiapas, Mexico. Geology, 6: 328-332. 
Burkart, B., 1983. Neogene North American-Caribbean plate boundary: Offset along the Polochic fault. Tectonophysics, 99: $251-270$.

Burkart, B. and Self, S., 1985. Extension and rotation of crustal blocks in northern Central America and effect on the volcanic arc. Geology, 13: 22-26.

Burkart, B., Beaton, B.C., Dengo, C., and Moreno, G., 1987. Tectonic wedges and offset Laramide structures along the Polochic fault of Guatemala and Chiapas, Mexico: Reaffirmation of large Neogene displacement. Tectonics, 6: 411-422.

Campa, M.F., and Coney, P.J., 1983. Tectonostratigraphic terranes and mineral resource distributions in Mexico. Can. J. Earth Sci., 20: 1040-1051.

Carr, M.J., 1984. Symmetrical and segmented variation of physical and geochemical characteristics of the Central America volcanic front. J. Volcanol. Geotherm. Res., 20: 231-252.

Damon, P.E. and Montesinos, E., 1978. Late Cenozoic volcanism and metallogenesis over an active Benioff zone in Chiapas, Mexico. Ariz. Geol. Soc. Digest, 11: 155-168.

Dengo, G., 1969. Problems of tectonic relation between Central Amcrica and the Caribbean. Trans. Gulf Coast Assoc. Geol. Soc., 19: 311-320.

Gose, W.A., 1985. Paleomagnetic results from Honduras and their bearing on Caribbean tectonics. Tectonics, 4: 565585.

Guerrero, J.C., Helsley C.H. and Herrero-Bervera, E., 1990. Paleomagnetic evidence for post Jurassic stability of southeastern Mexico: Maya terrane. J. Geophys. Res., 96: 70917100.

Guzman-Speziale, M., Pennington, W.D. and Matumoto, T., 1989. The triple junction of the North America, Cocos, and Caribbean plates: seismicity and tectonics. Tectonics, 8: $981-997$.

Holcombe, T.L. and Sharman, G.F., 1983. Post-Miocene Cayman Trough evolution: A speculative model. Geology, 11: $711-714$

Irving, E. and Irving G.A., 1982. Apparent polar wander paths Carboniferous through Cenozoic and the assembly of Gondwana. Geophys. Surv., 5: 141-188.

Jordan, T.H., 1975. The present-day motions of the Caribbean plate. J. Geophys. Res., 80: 4433-4439.

Kirschvink, J.L., 1980. The least squares line and plane and analysis of paleomagnetic data. Geophys. J.R. Astron. Soc., 45: 699-718.

Mammerickx, J. and Klitgord, K.D., 1982. Northern East Pacific rise: evolution 25 my BP to present. J. Geophys. Res., 87: 6751-6759.

Meneses-Rocha, J., 1985. Tectonic evolution of the strike slip province of Chiapas, Mexico. M.A. Thesis, Univ. of Texas. Austin, $351 \mathrm{pp}$

Molina-Garza, R.S., Van der Voo, R. and Urrutia-Fucugauchi, J., 1992. Paleomagnetism of the Chiapas Massif, southern Mexico: Evidence for rotation of the Maya Block and implication for the opening of the Gulf of Mexico. Geol. Soc. Am. Bull., 104: 1156-1168.

Molnar, P. and Sykes, L.R., 1969, Tectonics of the Caribbean and Middle America regions from focal mechanisms and seismicity. Geol. Soc. Am. Bull., 80: 1639-1684.

Pindell, J.L. and Barrett, S.F., 1990. Geologic evolution of the Caribbcan region: A platc tectonic pcrspcctivc. In: J.E. Case and G. Dengo (Editors), The Geology of North America, vol. H. Geol. Soc. Am., Boulder, CO, pp. 405432.

Rosencrantz, E., Ross, E. and J.G. Sclater, J.G., 1988. Depth and spreading history of the Cayman Trough as determined from depth, heat flow, and magnetic anomalies. $J$. Geophys. Res., 93: 2141-2157.

Ross, M.I., and Scotese, C.R.. 1988. A hierarchical tectonic model of Mexico and the Caribbean region. Tectonophysics, 155: 139-168.

Schwartz, D.P., Cuff, L.S. and T.W. Donnelly, TW., 1979. Quaternary faulting along the Caribbean-North American plate boundary in Central America. Tectonophysics, 52: 431-445.

Tolson, G., Solis-Pichardo, G., Moran, D.J., Victoria-Morales, A. and Treviño, J., 1993. Naturaleza petrografica y estructural de las rocas cristalinas de la zona de contacto entre los terrenos Xolapa y Oaxaca, region de Santa Maria, Oaxaca. Monogr. Union Geofisica Mexicana, 1: 327-349.

Urrutia-Fucugauchi, J., 1987. Lateral migration of igneous activity in the Chiapas magmatic arc, southern Mexico. Litosfera, 1: 13-21.

Urrutia-Fucugauchi, J., 1988. Paleomagnetic study of the Cretaceous Morelos Formation, Guerrero State, southern Mexicu. Tectonophysics, 147: 121-125.

Urrutia-Fucugauchi, J. and Böhnel, H., 1988. Tectonics along the Trans-Mexican volcanic belt according to paleomagnetic data. Phys. Earth Planet. Inter., 52: 320-329.

Urrutia-Fucugauchi, J., Moran-Zenteno, D.J. and CabralCano E., 1987. Paleomagnetism and tectonics of Mexico. Geofis. Int., 26: 429-458.

Viniegra, F.O., 1971. Age and evolution of salt basins of southeastern Mexico. Am. Assoc. Pet. Geol. Bull., 55: $478-494$.

Zijderveld, J.D.A., 1967. A.C. demagnetization of rocks: Analysis of results. In: D.W. Collinson and S.K. Runcorn (Editors), Methods in Paleomagnetism. Elsevier, Amsterdam, pp. 245-86. 